\title{
Book Review of Waking Up White and Finding Myself in the Story of Race Samuel A. Nigro*
}

Case Western Reserve University School of Medicine, Ohio, USA

"Corresponding author: Samuel A. Nigro, Case Western Reserve University School of Medicine, Ohio, USA, E-mail: sam@docnigro.com

Received date: March 25, 2016; Accepted date: May 21, 2016; Published date: May 27, 2016

Copyright: (c) 2016 Nigro SA. This is an open-access article distributed under the terms of the Creative Commons Attribution License, which permits unrestricted use, distribution, and reproduction in any medium, provided the original author and source are credited.

\section{Book Review}

This is the author's full page quote before contents: "If I love you, I must make you conscious of things you do not see." James Baldwin.

And that the author tries to do as she apologetically describes her "white" life to embrace blackness and otherness in a moving and valiant attempt to go beyond her whiteness. Many go through this after becoming aware of the evils of oppressive slavery and become apologists, sometimes "duped apologists" for blacks. This is usually a phase and one moves on to a "consciousness of things not seen" such as full humanity-without-colour, finally identifying transcendentally as "content of character" rather than fragmentation due to melanin contained in the tip of a lead pencil (the amount of melanin in the darkest black person). An irving still need Baldwin's words, but her story is well worth knowing as a first step to genuine human oneness rather than oxymoron's of colour.

Her blindness begins with the sanctification of Native Americans with no awareness of their violence and murderous slavery. My grandfather's story came to mind: In central Kansas in the 1800s, Indian tribes would come to Wacanda Springs for religious sacrifice. All the farmers would gather to show protective force obtaining tense cooperation. The ceremonies proceeded with the farmers always prohibiting the Indians' usual sacrifice of a few young Indian girls to be killed and thrown into the sacred waters. Also, the retaliatory consequences of any plunder and murder of isolated farms, as once was routine, was made clear to these "innocent savages".

Irving's details on the "the first attempt to categorize humans by skin colour" was illuminating, but she then imposes negativity:

"During these same years, white European colonization of Asia, Africa, and the Americas was gathering speed, fuelling ideas of white dominance and superiority. Entangled in all of this were white European missionaries bringing Christianity to far-flung parts of the world. In this case, the white way was not only better in this world but a requirement for entrance to heaven".

Irving is oblivious that power would corrupt any culture which was the first to learn how to sail against the wind. Interestingly, she blindly contradicts herself when she quotes Edmund Burke: "All that is necessary for evil to triumph is for good men to do nothing" unless dealing with black cannibals or slave torturing Indians or child selling Muslims? She also quotes Mahatma Gandhi: "Be the change that you wish to see in the world" (words well lived by Stalin and Hitler) to which must be added "at least Greek virtue" to Gandhi's "change" because "prudence, justice, temperance, and fortitude" (and other virtues) will be needed if a "good" outcome is to be expected.

"If racism were a person, they would definitely be a bully". But she overlooks that victimhood can sometimes be "bullying" too. Irving creates oxymoron's (i.e., "a deafening silence") galore in this book. "White privilege" is a bad positive while "black victimhood" is a good negative (or to repeat respectively: "negative-positive" and "positivenegative") as if some whites did not have to work for what they have and as if some black deprivations are not affirmatively embraced.

The author's obsessional oxymoron-creating peaked on page 197 with a list of behavioural "continuums" categorized as "white" on the left column and "racial healing" on the right. Just so if all is seen as "black and white" and all the world is an oxymoron.

The book closes with profound statements from Father Gregory Boyle, "When we relearn our loveliness, we begin to foster tenderness for our own human predicament. A spacious and undefended heart finds room for everything you are and carves enough space for everyone else." Unembarrassed, I offer a "loveliness" needing promulgation more than victimhood, colour, and spurious racism: The "loveliness" of the end of slavery: One and a half million Caucasians died in combat or military related activities defeating the South to end slavery $[1,2]$.

That is three Caucasians died for each of the 450,000 African slaves imported into the Americas from about 1765 to 1865 . The same three Caucasians died for every eight American slaves freed among the four million slaves in America at the end of the civil war. Those four million slaves have over thirty-five million descendants in the U.S. over twenty five to thirty millions of slave descendants are successful using the educational, occupational, and family opportunities available in the U.S.

Another twenty million Caucasians of the North sacrificed and worked hard in the Civil War to support the slavery ending Caucasian army-they too have many descendants who are successful today. All groups still have some members needing help-and life remains as hard as ever for most. Real humans continue help each other and do not become hostile victimhood beggars. To allow anyone to live a lie is not going to help them.

The paradigms of colour and race do not work but harden the heart and melt the brain, because humanbeingness is fragmented and destroyed. All need to focus on "the content of character" from Dr King and the "quality of intent" from Justice Thurgood Marshall, both teaching, living, and dying for Truth, Oneness, Good and Beautywhich is Loveliness rarely found with mention of colour or race. "Waking up human" is the answer.

\section{References}

1. Nigro SA (2000) Review of The Popes and Slavery. Social Justice Review pp: 110-111. 
Citation: Nigro SA (2016) Book Review of Waking Up White and Finding Myself in the Story of Race. Clin Depress 2: 111. doi: 10.4172/2572-0791.1000111

Page 2 of 2

2. Nigro SA (2001) The American Killing Syndrome The Satanic Supreme Ethnic Cleanser. Social Justice Review pp: 185-188. 